\title{
Strenghts of Character of Personal Growth: Structure and Relations with the Big Five in the Brazilian Context ${ }^{1}$
}

\author{
Ana Paula Porto Noronha ${ }^{2}$, Cristian Zanon ${ }^{2}$ \\ ${ }^{2}$ Universidade São Francisco, Campinas-SP, Brazil
}

\begin{abstract}
The structure of character strengths and virtues in different cultural contexts across the globe has failed to recover the sixfactor solution originally proposed by Peterson and Seligman. This study aims to assess the structure of the Character Strengths Scale, a test created to assess character strengths and virtues and the association between these strengths and personality factors in the Brazilian context. The sample was made up of 981 undergraduate students ( $60.5 \%$ female) aged between 17 and 26 years $(M=20.7, S D=2.2)$, who responded the Character Strengths Scale and Personality Factors Battery. Exploratory factor analysis indicated that the threefactor solution was the most theoretically appropriate, identifying the following factors: Intellectual Strengths, Intrapersonal Strengths and Collectivism, and Transcendence. Regression analysis showed that three personality factors (conscientiousness, extraversion and neuroticism) are relevant predictors of these strengths, explaining a considerable amount of variance. The implications of the findings are presented, suggesting that high levels of neuroticism may impair the flourishing of strengths.
\end{abstract}

Keywords: positive psychology, personality, psychological assessment

\section{Forças de Caráter do Crescimento Pessoal: Estrutura e Relações com o Big Five no Contexto Brasileiro}

\begin{abstract}
Resumo: A estrutura de forças e virtudes em todo o mundo não tem conseguido recuperar a solução de seis fatores proposta originalmente por Peterson e Seligman. Este estudo tem como objetivo avaliar a estrutura da Escala de Força de Caráter, teste criado para avaliar forças e virtudes no contexto brasileiro e suas relações com fatores de personalidade. Participaram 981 estudantes de graduação $(60,5 \%$ do sexo feminino), com idade entre 17 e 26 anos $(M=20,7, D P=2,2)$ que responderam a Escala de Força de Caráter e Bateria Fatorial de Personalidade. A análise fatorial exploratória indicou a solução de três fatores como a mais apropriada teoricamente, identificando os fatores: Intelecto, Intrapessonal e Coletivismo e Transcendência. Modelos de regressão apontaram que três fatores de personalidade (conscienciosidade, extroversão e neuroticismo) constituem preditores relevantes dessas forças. Implicações destes resultados são apresentadas, sugerindo que altos níveis de neuroticismo podem prejudicar o florescimento das forças.
\end{abstract}

Palavras-chave: psicologia positiva, personalidade, avaliação psicológica

\section{Fuerzas de Carácter del Crescimento Personal: Estrutura y Relaciones com los Big Five em el Contexto Brasileño}

\begin{abstract}
Resumen: La estructura de fuerzas y virtudes en todo el mundo no ha podido recuperar la solución de seis factores originalmente propuesta por Peterson y Seligman. Este estudio tiene como objetivo evaluar la estructura de la Escala de Fortalezas de Carácter - una prueba creada para el contexto brasileño para evaluar fuerzas y virtudes y evaluar sus relaciones con factores de personalidad. Los participantes fueron 981 estudiantes de pregrado (60,5\% mujeres), de edades comprendidas entre los 17 y los 26 años ( $M=20,7$, $S D=2,2)$ que respondieron a la Escala de Fuerzas de Carácter ya la Batería Factorial de Personalidad. El análisis factorial exploratorio indicó la solución de tres factores como la más apropiado (identificando los factores: Intelecto, Intrapersonal y Colectivismo, y Transcendencia) y los modelos de regresión apuntaran que tres factores de personalidad (conciencia, extraversión y neuroticismo) constituyen predictores relevantes de estas fuerzas. Las implicaciones de estos resultados se presentan sugiriendo que altos niveles de neuroticismo pueden afectar el florecimiento de las fuerzas.
\end{abstract}

Palabras clave: psicología positiva, personalidad, evaluación psicológica

\footnotetext{
${ }^{1}$ Support: Graduate Program in Psychology at the Universidade São Francisco.

Correspondence address: Ana Paula Porto Noronha. Universidade São Francisco. Programa de Pós-graduação Stricto Sensu em Psicologia. Rua Waldemar César da Silveira, n⿳ 105, Bairro Jardim Cura D'ars, CampinasSP, Brazil. CEP 13.045-510. E-mail: ana.noronha8@gmail.com
}

Strengths and virtues are desirable characteristics for personal growth and interpersonal adequacy. While virtues comprise specific individual capacities related to patterns of thoughts, feelings, and actions, each one with its specific underlying strengths, character 
strengths involve characteristics that produce general positive functioning. Both are highly valued because they facilitate the development of tasks that are essential to the survival of the human species (Peterson \& Seligman, 2004). These authors categorized and described six clusters of "universal" human strengths (Wisdom and Knowledge, Courage, Humanity, Justice, Temperance, and Transcendence). However, subsequent studies failed to find the same structure (Park \& Peterson, 2006; Ruch, Weber, Park, \& Peterson, 2014; Toner, Haslam, Robinson, \& Williams, 2012; van Eeden, Wissing, Dreyer, Park, \& Peterson, 2008). Given that alternative solutions have been proposed to encompass the different virtues embodied by different cultures, this study explores the structure proposed by Peterson and Seligman in the collectivistic culture of Brazil. Features associated with collectivism include being concerned with the ingroup's fate and giving its goals priority over one's own and avoiding open conflict within the ingroup (Rhee, Uleman, \& Lee, 1996). Previous research suggests that Brazilians possess collectivistic features, since they tend to internalize ingroup norms and are more likely than Americans to do, and also enjoy doing, what is expected of them (Bontempo, Lobel, \& Triandis, 1990). The development of given strengths and virtues is influenced by certain personality traits and therefore this study also aims to explore the relationship between the character strengths proposed by Peterson and Seligman and the Big Five personality traits.

Peterson and Seligman (2004) suggested a certain degree of correspondence between the structure of strengths and personality factors. For example, they suggested that curiosity and love of learning are related to openness to experience, teamwork is associated with agreeableness, persistence with conscientiousness, leadership with extraversion, and that hope is related to certain aspects of emotional stability.

Evidence supports an association between character strengths and virtues and the Big Five, highlighting that the five personality factors are strong predictors of the 24 virtues (Littman-Ovadia \& Lavy, 2012; Macdonald, Bore, $\&$ Munro, 2008). Neto, Neto and Furnham (2013) found low-magnitude associations between character strengths and the Big Five personality traits. The traits most associated with strengths were socialization, openness and achievement, emphasizing the correlation between socialization and the grouped strengths kindness, love and vitality, citizenship, gratitude, forgiveness, humor, and authenticity, combined in a group. Neuroticism and extraversion showed null (nonsignificant) correlations. Other studies have shown that creative people tend to have greater openness to experience and show stronger socialization (King, Walker, \& Broyles, 1996), that forgiveness was negatively associated with neuroticism and positively associated with socialization and, to a lesser extent, extraversion (Brose, Rye, Lutz-Zois, \& Ross, 2005), and that neuroticism was negatively related to hope and courage and socialization may be a predictor of spirituality negatively related to hope and courage and socialization may be a predictor of spirituality (Macdonald et al., 2008).

In Brazil, Noronha and Barbosa (2016) developed the Character Strengths Scale (CSS), based on the Values in Action (VIA-IS) (Peterson \& Seligman, 2004). A study conducted by Noronha, Dellazzana-Zanon, and Zanon (2015) using factor analysis and robust retention methods such as parallel analysis and the Hull method revealed a unidimensional solution with an alpha coefficient of .93. Seibel, De Souza, and Koller (2015) adapted the VIA-IS for use in Brazil. Exploratory factor analysis was performed using the character strength scores to determine the factor structure of the virtues of the Brazilian version of the questionnaire. The Hull method resulted in the extraction of a single factor, while parallel analysis resulted in the extraction of three or four factors. According to the authors, these findings suggest that different interpretations of the structure can occur depending on the culture in which the VIA-IS is applied. Using a new sample, this paper explores the internal structure of character strengths in Brazil and the association between these strengths and personality traits. Preliminary evidence suggests that the structure of strengths in Brazil is best represented by a unidimensional solution. Since validity is not a property of the test itself, but rather a property of the test score (American Educational Research Association [AERA], American Psychological Association [APA], and National Council on Measurement in Education [NCME], 2014), a new study was conducted to assess internal structure using a larger and more representative sample.

\section{Method}

\section{Participants}

Using convenience sampling, the current study recruited 981 undergraduate students $(60.5 \%$ female $)$ from two private universities in the States of São Paulo and Minas Gerais from the following courses: Engineering (30\%), Psychology (27\%), Architecture (19\%), Biomedicine (9\%), Nursing (7\%), Pharmacy (4\%), and Pedagogy (4\%). The final sample was made up of students aged between 17 and 26 years $(M=20.7, S D=2.2)$; those aged over 26 years (less than $15 \%$ of the total sample) were excluded to ensure comparability with other international studies. The students received no payment for participating in the study.

\section{Instruments}

Character strengths. Noronha and Barbosa adjusted (2016) Peterson and Seligman's model (2004) to fit the Brazilian culture, creating the Brazilian character strengths scale (Escala de Forças de Caráter). This scale presents validity for the unidimensional structure and evidence of reliability for this solution - alpha coefficient 
of over .90 (Noronha et al., 2015). The scale comprises 71 virtue statements answered on a five-point Likert-type scale (ranging from $0=$ "not at all like me" to 4 = "very much like me") representing 24 strengths. Each of the strengths is made up of three items, except the strength appreciation of beauty, with only two items. Character strength scores were calculated based on the sum of the respective item scores. The test did not contain any negative items.

The Personality Factors Battery (BFP). The Bateria Fatorial de Personalidade (BFP, acronym in Portuguese), developed by Nunes, Hutz, and Nunes (2008) is a self-report instrument modeled on the Five-Factor Model comprising 126 items. The test has been shown to have validity as a fivedimensional scale (based on an assessment of its internal structure) for assessing the five personality factors and their different facets (although facets were not analyzed in the present investigation). The items contained in the BFP are answered using a Likert-type scale ranging from 1 (does not describe me at all) to 7 (describes me very well). The alpha coefficient was found to be adequate for each of the five factors: neuroticism .89, extraversion .84, agreeableness .85 , conscientiousness .83 , and openness .74 .

\section{Procedure}

Data collection. The students' professors were contacted to ask permission to carry out data collection during class time. Students were subsequently invited to take part in the study. Participants completed group questionnaire in their classrooms. This process lasted between 35 and 45 minutes. The participants' raw scores were inputted into an excel spreadsheet in accordance with the tests' data entry rules.

Data analysis. Analytical procedures. The 24 strengths were analyzed by factor using maximum likelihood with robust standard errors (MLR) and Geomin rotation. This extraction method was chosen since it is appropriate for skewed data, while oblique rotation allows factors to be correlated (Muthén \& Muthén, 2015). We assessed factorial solutions for factors 1 to 6 , performed parallel analysis (Horn, 1965), and considered traditional fit indices (Chi-square, RMSEA, and CFI) to obtain evidence on the number of factors. A nonsignificant $\mathrm{c}^{2}$, RMSEA value of less than .08, and CFI $>.90$ is generally considered a good fit $(\mathrm{Hu}$ $\&$ Bentler, 1999). Because the $\mathrm{c}^{2}$ test is sensitive to sample size and tends to be significant when sample size is large (Kline, 2011), our factor retention decision was ultimately based on RMSEA and CFI, given that all models showed significant $\mathrm{c}^{2}$ values. Finally, we applied three multiple regression models to measure the predictive power of personality factors for explaining strengths.

\section{Ethical Considerations}

This study was conducted in accordance with ethical principles applied to research with human beings. The research project was approved by the Ethics Committee of the University of São Francisco (application number: 20410713.3.0000.5514).

\section{Results}

\section{Factor Analyses}

Dimensionality. Parallel analysis indicated that three factors should be retained, while the fit indices indicated that solutions with more dimensions presented a better fit (Table 1). However, only the one-factor and three-factor solutions showed theoretically acceptable interpretations. In the one-factor solution, all strengths showed factor loadings of over .40, while the three-factor solution identified factors already described by the literature. Three strengths (authenticity, beauty, and humor) were excluded because they showed factor loadings of less than .30 for the three selected factors. The fit improved after deleting these items $(\mathrm{RMSEA}=.065, \mathrm{CFI}=.905)$. Table 2 presents the final three-factor solution, comprising Intellectual Strengths, Intrapersonal Strengths and Collectivism, and Transcendence. Five strengths had cross-loadings (OpenMindedness, Fairness, Vitality, Kindness, and Forgiveness), while only two strengths loaded higher for the unexpected factor (Open-Mindedness and Vitality). This may be because the strengths are not purely unidimensional. All loadings for the expected factor were significant.

Table 1

Assessment of the Dimensionality of the Character Strengths Scale

\begin{tabular}{lcccc}
\hline Model Tested & NFParm & $\chi^{2}$ & RMSEA & CFI \\
\hline 1-factor & 72 & 2210.183 & .089 & .737 \\
2-factor & 95 & 1513.651 & .076 & .828 \\
3-factor & 117 & 1073.447 & .065 & .884 \\
4-factor & 138 & 756.514 & .056 & .923 \\
5-factor & 158 & 644.308 & .054 & .936 \\
6-factor & 177 & 592.175 & .056 & .940 \\
\hline
\end{tabular}


Table 2

Factor loadings of the three-factor solution for the Character Strengths Scale (MLR, Geomin Rotated)

\begin{tabular}{|c|c|c|c|}
\hline & \multicolumn{3}{|c|}{ Factors } \\
\hline Strengths & $\begin{array}{l}\text { Intellectual } \\
\text { Factor } 1\end{array}$ & $\begin{array}{c}\text { Intrapersonal and } \\
\text { collectivism } \\
\text { Factor } 2\end{array}$ & $\begin{array}{c}\text { Transcendence } \\
\text { Factor } 3\end{array}$ \\
\hline Curiosity & .845 & -.096 & .008 \\
\hline $\begin{array}{l}\text { Love of } \\
\text { learning }\end{array}$ & .749 & -.01 & .048 \\
\hline Creativity & .500 & .266 & -.115 \\
\hline Persistence & .462 & .180 & .212 \\
\hline $\begin{array}{l}\text { Open- } \\
\text { Mindedness }\end{array}$ & .333 & .480 & -.146 \\
\hline Prudence & .054 & .628 & -.027 \\
\hline Perspective & .144 & .591 & -.009 \\
\hline $\begin{array}{l}\text { Self- } \\
\text { Regulation }\end{array}$ & .008 & .518 & .073 \\
\hline Modesty & -.119 & .456 & .259 \\
\hline Fairness & -.009 & .437 & .316 \\
\hline Leadership & .295 & .416 & .113 \\
\hline Citizenship & .278 & .386 & .234 \\
\hline $\begin{array}{l}\text { Social } \\
\text { Intelligence }\end{array}$ & .099 & .373 & .254 \\
\hline Bravery & .285 & .323 & .057 \\
\hline Gratitude & .036 & -.018 & .824 \\
\hline Spirituality & .032 & -.038 & .713 \\
\hline Hope & .233 & .001 & .611 \\
\hline Love & .06 & .123 & .527 \\
\hline Vitality & .311 & .009 & .506 \\
\hline Kindness & -.006 & .326 & .463 \\
\hline Forgiveness & -.094 & .326 & .393 \\
\hline
\end{tabular}

\section{Regression Models}

Table 3 presents the results of the multiple regression analyses. Due to time constraints, some of the participants did not answer the personality test $(N=334)$. The first model, used to predict Intellectual Strengths, achieved an explained variance of $50 \%$ and the most significant predictors were $\mathrm{C}, \mathrm{E}$, and $\mathrm{N}$ (inversely related) - only $\mathrm{A}$ did not show a significant regression coefficient. The second model, used to predict Intrapersonal Strengths and Collectivism, achieved an explained variance of $45 \%$ and the most significant predictors were $\mathrm{C}$ and $\mathrm{N}$ (inversely related). E and A also showed significant, albeit low, regression coefficients. Finally, the third model, used to predict Transcendence, achieved an explained variance of $37 \%$ and the most significant predictors were $\mathrm{E}$ and $\mathrm{N}$ (inversely related). All personality factors showed significant, albeit low, regression coefficients.
Table 3

Multiple Regression Models Representing Strengths

(Enter Method - $N=334$ )

\begin{tabular}{|c|c|c|c|c|c|c|c|c|c|}
\hline \multirow[b]{2}{*}{ Variables } & \multicolumn{3}{|c|}{$\begin{array}{l}\text { Intellectual } \\
\text { strengths }\end{array}$} & \multicolumn{3}{|c|}{$\begin{array}{l}\text { Intrapersonal } \\
\text { strengths and } \\
\text { collectivism }\end{array}$} & \multicolumn{3}{|c|}{ Transcendence } \\
\hline & $\beta$ & $p$ & $\mathrm{R}^{2}$ & $\beta$ & $p$ & $\mathrm{R}^{2}$ & $\beta$ & $p$ & $\mathrm{R}^{2}$ \\
\hline $\mathrm{O}$ & .103 & .029 & & -.007 & .880 & & -.147 & .03 & \\
\hline $\mathrm{C}$ & .403 & .001 & & .434 & .001 & & .153 & .003 & \\
\hline $\mathrm{E}$ & .334 & .001 & & .171 & .001 & & .417 & .001 & \\
\hline A & .009 & .863 & & .164 & .003 & & .157 & .009 & \\
\hline $\mathrm{N}$ & -.223 & .001 & & -.305 & .001 & & -.273 & .001 & \\
\hline
\end{tabular}

Note. $\mathrm{O}=$ Openness, $\mathrm{C}=$ Conscientiousness, $\mathrm{E}=$ Extraversion, $\mathrm{A}=$ Agreeableness, $\mathrm{N}=$ Neuroticism, $p<.05, p<.01$

\section{Discussion}

This study assessed the internal structure of a measure of character strengths in Brazil and its association with personality traits. Our findings show that the only theoretically meaningful solution was the three-factor structure. These findings do not corroborate the Peterson and Park (2004) model or the results of previous studies conducted in Brazil by Noronha et al. (2015) and Seibel et al. (2015). They also show that there is a considerable association between these factors and conscientiousness, extraversion and neuroticism from the Big Five model. According to Seibel et al. (2015), different interpretations of factors can occur in different cultural contexts.

\section{The structure of strengths in Brazil}

Our three-factor solution features factors that are similar to those proposed by other studies. The first factor, which we have called Intellectual Strengths, is made up of strengths such as curiosity, love of learning, creativity, persistence, and critical thinking. A similar corresponding factor has been proposed by other authors such as LittmanOvadia and Lavy (2012), for example, who called it Intellectual Strengths, Brdarand Kashdan (2010), who called it fortitude, and Macdonald et al. (2008), who also called it Intellectual Strengths. The second factor, which we have called Intrapersonal and Collectivity, encompasses strengths like identification, emotional regulation, modesty, bravery, and social justice. It is partially reminiscent of the strengths underlying the "positivity" factor described by Littman-Ovadia and Lavy (2012), but distinct from the corresponding factor outlined by Brdar and Kashdan (2010) and Macdonald et al. (2008). With respect to Peterson and Park's (2004) model, the strengths underlying this factor can be found in five of the six virtues - only the strengths related to transcendence did not load on this factor. This factor clusters together strengths that are highly valued in organizational environments in Brazil focused on the 
development of honest and collaborative workers. The third factor, called Transcendence, grouped gratitude, spirituality, optimism/hope, love, vitality and forgiveness. This factor is very similar to its corresponding factor in Peterson and Park's (2004) model of the same name. Our transcendence factor has a similar constitution to Macdonald et al. (2008) kindness factor.

\section{Character Strengths and Personality Traits}

The results of regression analysis show that personality traits explained a considerable amount of variance in our three-factor solution (from $0.37 \%$ to $50 \%$ ), particularly in the intellectual strengths factor. Surprisingly, openness to experience was not the most significant predictor of relevant intellectual strengths. Although significant, openness played a lesser role than conscientiousness, extraversion and neuroticism. These findings suggest that, although characteristics like persistence, dedication, emotional regulation, and social interaction may be key personality traits related to intellectual strengths, imagination and novelty also play a role.

The second regression model showed that conscientiousness and neuroticism were (inversely) the most significant predictors related to intrapersonal strengths and collectivism, rather than extraversion and agreeableness. Since this factor is composed mainly of strengths that require strong cognitive and emotional regulation (for example, prudence, regulation, and modesty), conscientiousness and neuroticism became stronger predictors. However, extraversion and agreeableness also showed significant regression coefficients, indicating that traits such as interpersonal collaboration, engagement and interaction are likely to be important traits. Similar findings were observed in a study conducted by Furnham and Lester (2012); however these results are not corroborated by other studies (Macdonald et al., 2008; Neto et al., 2014).

The third regression model showed that all five personality factors are significant predictors of transcendence. The predictors that had the greatest effect were extraversion and neuroticism, which suggests that people who are introverted and depressed may experience more difficulty in becoming enthusiastic and open in relation to religion and mysticism.

\section{Implications of the Findings}

The three-factor solution found in this sample shows that several different values (originally belonging to distinct strengths) cluster together with broader factors. The three excluded factors may reflect not only the specificities of the sample, composed of Brazilian college students, but also those of Brazilian culture. Intellectual strengths, intrapersonal strengths and collectivism are essential characteristics for ensuring successful adaptation to the college or university setting, because they facilitate engagement, learning, achievement, and student-student and student-professor interaction. It could be said that transcendence values characterize the highly valued beliefs of Brazilians, who live in a particularly religious culture in which Catholicism and Afro-descendant religions maintain a presence among the most of the population (Instituto Brasileiro de Geografia e Estatística - IBGE, 2010).

The role played by personality in the development of character strengths is critical, suggesting that people who are more neurotic are less likely to develop strengths related to self and interpersonal regulation, which can lead to an increase in anxiety, stress, and depression. On the other hand, traits such as conscientiousness, extraversion, and agreeableness are likely to facilitate the development of intellectual and personal strengths that increase self and interpersonal emotion regulation. Thus, interventions to promote flourishing of strengths should take into account the fact that high levels of neuroticism may impair or even block the development of desired positive characteristics.

One of the limitations of this study is the homogenous nature of the sample population, which was composed solely of college students, thus hampering generalizability. Another limitation was the correlational method used for this study, which did not allow for the assessment of causal relations between personality and virtues. In other words, it was not possible to determine whether personality contributes to the development of strengths or vice-versa. However, the main strength of this study was that assessment tools used to gauge personality and virtues were developed specifically for the Brazilian context, thus eliminating biases related to test adaptation. Future studies should investigate the structure of the Virtues Scale using population-based samples in order to provide more comprehensive results and ensure generalization.

\section{References}

American Educational Research Association, American Psychological Association, \& National Council on Measurement in Education. (2014). The standards for educational and psychological testing (6th ed.). Washington, DC: American Educational Research Association.

Bontempo, R., Lobel, S., \& Triandis, H. (1990). Compliance and value internalization in Brazil and the U.S: Effects of allocentrism and anonymity. Journal of Cross-Cultural Psychology, 21(2), 200-213. doi:10.1177/0022022190212004

Brdar, I., \& Kashdan, T. B. (2010). Character strengths and wellbeing in Croatia: An empirical investigation of structure and correlates. Journal of Research in Personality, 44(1), 151-154. doi:10.1016/j.jrp.2009.12.001

Brose, L.A., Rye, M. S., Lutz-Zois, C., \& Ross, S. R. (2005). Forgiveness and personality traits. Personality and Individual Differences, 39(1), 35-46. Retrieved from http://ecommons.udayton.edu/psy_fac_pub/20

Furnham, A., \& Lester, D. (2012). The development of a short measure of character strength. European Journal of Psychological Assessment, 28(2), 95-101. doi:10.1027/1015-5759/a000096 
Horn, J. L. (1965). A rationale and test for the number of factors in factor analysis. Psychometrika, 30(2), 179-185. doi:10.1007/BF02289447

Hu, L.-T., \& Bentler, P. M. (1999). Cutoff criteria for fit indexes in covariance structure analysis: Conventional criteria versus new alternatives. Structural Equation Modeling, 6(1), 1-55. doi:10.1080/10705519909540118

Instituto Brasileiro de Geografia e Estatística. (2010). Censo Demográfico2010: Características gerais da população, religião e pessoas com deficiência. Rio de Janeiro, RJ: IBGE. Retrieved from https://biblioteca.ibge.gov.br/visualizacao/ periodicos/94/cd_2010_religiao_deficiencia.pdf

King, L. A., Walker, L. M., \& Broyles, S. (1996). Creativity and the five-factor model. Journal of Research in Personality, 30(2), 189-203.doi:10.1006/jrpe.1996.0013

Kline, R. B. (2011). Principles and practice of structural equation modeling (3rd ed.). New York, NY: Guilford.

Littman-Ovadia, H., \& Lavy, S. (2012). Character strengths in Israel: Hebrew adaptation of the VIA inventory of strengths. European Journal of Psychological Assessment, 28(1), 41-50. doi:10.1027/1015-5759/ a000089

Macdonald, C., Bore, M., \& Munro, D. (2008). Values in action scale and the Big 5: An empirical indication of structure. Journal of Research in Personality, 42(4), 787-799. doi:10.1016/j.jrp.2007.10.003

Muthén, L. K., \& Muthén, B. O. (2015). Mplususer's guide:Version 7.4. Los Angeles, CA: Muthén \& Muthén.

Neto, J., Neto, F., \& Furnham, A. (2014). Gender and psychological correlates of self-rated strengths among youth. Social Indicators Research, 118(1), 315-327. doi:10.1007/s11205-013-0417-5

Noronha, A. P. P., \& Barbosa, A. J. G. (2016). Escala de forças de caráter: Construção e estudos psicométricos [Caracter and streangths scale: Construction and psychometric studies]. In C. S. Hutz (Org.), Avaliação em psicologia positiva (pp. 21-43). São Paulo, SP: Hogrefe.

Noronha, A. P. P., Dellazzana-Zanon, L. L., \& Zanon, C. (2015). Internal structure of the characters strengths scale in Brazil. Psico-USF, 20(2), 229-235. doi:10.1590/1413-82712015200204

Nunes, C. H. S. S., Hutz, C. S., \& Nunes, M. F. O. (2008). Bateria Fatorial de Personalidade (BFP) [Factorial Personality Battery]. São Paulo, SP: Casa do Psicólogo.

Park, N., \& Peterson, C. (2006). Moral competence and character strengths among adolescents: The development and validation of the Values in Action Inventory of Strengths for Youth. Journal of Adolescence, 29(6), 891-909. doi:10.1016/j.adolescence.2006.04.011
Peterson, C., \& Park, N. (2004). Classification and measurement of character strengths: Implications for practice. In P. A. Linley \& S. Joseph (Eds.), Positive psychology in practice (pp. 433-446). New York: John Wiley \& Sons.

Peterson, C., \& Seligman, M. E. P. (2004). Character strengths and virtues: $A$ handbook and classification. Washington, DC: American Psychological Association.

Rhee, E., Uleman, J. S., \& Lee, H. K. (1996). Variations in collectivism and individualism by in group and culture: Confirmatory factor analyses. Journal of Personality and Social Psychology, 71(5), 1037-1054. doi:10.1037/0022-3514.71.5.1037

Ruch, W., Weber, M., Park, N., \& Peterson, C. (2014). Character strengths in children and adolescents: Reliability and initial validity of the German Values in Action Inventory of Strengths for Youth (German VIAYouth). European Journal of Psychological Assessment, 30(1), 57-64. doi:10.1027/1015-5759/a000169

Seibel, B. L., DeSousa, D., \& Koller, S. H. (2015). Adaptação brasileira e estrutura fatorial da escala 240item VIA Inventory of Strengths [Brazilian adaptation and factor structure of the 240-item VIA Inventory of Strengths scale]. Psico-USF, 20(3), 371-383. doi:10.1590/1413-82712015200301

Toner, E., Haslam, N., Robinson, J., \& Williams, P. (2012). Character strengths and wellbeing in adolescence: Structure and correlates of the Values in Action Inventory of Strengths for Children. Personality and Individual Differences, 52(5), 637-642. doi:10.1016/j.paid.2011.12.014

van Eeden, C., Wissing, M. P., Dreyer, J., Park, N., \& Peterson, C. (2008). Validation of the Values in Action Inventory of Strengths for Youth (VIA-Youth) among South African learners. Journal of Psychology in Africa, 18(1), 143-154.

Ana Paula Noronha is a Professor of the Programa de Pós-Graduação em Psicologia of the Universidade São Francisco.

Cristian Zanon is a Professor of the Programa de Pós-Graduação em Psicologia of the Universidade São Francisco.

Received: Dec. 23, 2016

1st Revision: Apr. 18, 2017

Approved: Jun. 15, 2017

How to cite this article:

Noronha, A. P. P., \& Zanon, C. (2018). Strengths and virtues in Brazil: Structure and associations with the big five. Paidéia (Ribeirão Preto), 28, e2822. doi: http://dx.doi.org/10.1590/1982-4327e2822 